\title{
Technological Resources And Export Intensity: A Microview
}

José López Rodríguez, (E-mail: jolopez@udc.es), University of A Coruna, Spain Jesús López Rodríguez, (E-mail: jelopez@udc.es), University of A Coruna, Spain

\begin{abstract}
This article analyses the influence of technological resources on firm-export intensity. The empirical analysis is carried out on a sample of Spanish manufacturing firms using tobit models. Our findings show that $R \& D$ investments, product and process innovations and patents positively and significantly affect the export intensity of Spanish firms.
\end{abstract}

\section{INTRODUCTION}

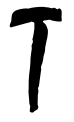

echnological resources are considered one of the main important factors for increasing firm's competitiveness. Firms that come into international markets must be very competitive because these markets are characterised for a quantitatively and qualitatively more advanced competition (Nassimbeni, 2001). The relationship between technological variables and exports has therefore attracted much attention in the economic literature, but the empirical results are quite controversial. Some studies show that R\&D investments, the most commonly technological variable used in the empirical literature, have a positive effect on export intensity (Ito and Pucik, 1993; Kumar and Siddhartam, 1994; Braunerhjelm, 1996; Basile, 2001; Roper and Love, 2002; Dhanaraj and Beamish, 2003; Gourlay and Seaton, 2003; Özçelik and Taymaz, 2004). Other studies (Wilmore, 1992; Lefebvre et al. 1998; Alonso and Donoso, 1998; Sterlacchini, 1999) do not find significant effects of R\&D investment on export intensity. Innovation process or product is another technological variable incorporated to export behaviour analysis, but again, the conclusions about its influence is mixed. The results of Basile, (2001) and Roper and Love (2002) show a positive effect on export intensity. Nevertheless, this assumption is not sustained by other authors (Wakelin, 1998).

Most of the empirical literature on the technology-exports relationship at the micro level is characterized by the use of a unique proxy variable for technology $-R \& D$ investment- (Nassimbeni, 2001). This reflects only a partial aspect of the technological dimension of firms, since apart from R\&D spending, innovations (of products and/or processes) and technologies protected by patents also form an important part of the technological resources of the firm. Another important feature of these studies is related with the use of cross-sectional data, what leads to the problem of causality of the relationships (Salomon and Shaver, 2000). Taking into account all of these general considerations our paper go deeper inside and differentiate from others by 1) using a broader measure for technological resources which include R\&D investment, product and process innovation and patents and 2) measuring with one-year lagged the independent variables.

The rest of this work is organised as follows. Section 2 analyses the strategic importance of the technological resources in the generation of competitive advantages and in particular its influence on firm-exporting activity. In the third section we describe the data and the methodology employed in the empirical analysis. Sections 4 and 5 present the empirical results and a discussion of the findings. Finally, in Section 6 we outline our main conclusions, and suggest some possible lines of research for the future. 


\section{TECHNOLOGICAL RESOURCES OF THE FIRM, CREATION OF COMPETITIVE ADVANTAGES AND EXPORT INTENSITY}

From the perspective of resource-based theory (Penrose, 1959; Wernerfelt, 1984) generating and sustaining competitive advantages resides in the set of strategic resources and capabilities available to the firm - i.e., the resources and capabilities that add value to the firm, do not have strategic substitutes and above all are either inimitable or difficult to imitate (Barney, 1991). Firm-resources tend to be classified into two types: tangible and intangible. Intangible resources are of great significance from the strategic perspective, since by their very nature and characteristics - information and knowledge-based - they are the resources that are most likely to fulfil the requirements for a resource to generate sustainable competitive advantages. Itami (1987) considers them to be the key resources for business success. In short, these are the business resources with the greatest competitive potential; hence their importance in firms' internationalisation processes in general and in their export activity in particular.

Intangible resources include a wide range of resources, among which we might mention technological capital, human capital, reputational capital and organisational capital (Grant, 1991). Of these, technological resources are one of the key factors for the generation of competitive advantages for firms. Technological resources are highly knowledge-intensive intangible assets. Much of this knowledge has a very important tacit component, that is difficult to codify (e.g., know-how); along with a high degree of specificity, which makes the resource more valuable into the firm than it would be outside, hindering its transference in the market; and complexity, in the sense that it is difficult to identify the causes that originate these resources (Kogut and Zander, 1993). All this makes these assets valuable, scarce and difficult for competitors to imitate. Thus, technological resources can easily fulfil the requirements for resources to generate and sustain competitive advantages, and they are hence a key resource in firms' expansion or internationalisation.

Technological resources can generate a double competitive advantage for a firm. On the one hand, they can confer competitive advantages in costs, via the development of new and more efficient productive processes. And on the other, they can confer competitive advantages based on differentiation, by means of product innovations, allowing the firm to tailor products according to customer requirements, or develop products of a higher quality. In this regard, Styles and Ambler (1994) point out that product strength in terms of quality and uniqueness is one of the key elements in export success. Similar considerations are to be found in Cavusgil et al. (1993), Madsen (1989), Burton and Schlegelmilch (1987) and Mcguinness and Little (1981). In the same line, various studies have noted that the ability of the firm to modify its products takes on more importance when it starts to enter foreign markets, since product management should take into account the variety of demands in international markets (Cavusgil and Zou, 1994; Kirpalani and MaCintosh, 1980). Moreover, the current environment - characterised by globalisation along with market segmentation and customers' increasing demand for customized products - is pushing the balance in favour of competition via differentiation. Thus, firms that have a superior technological capacity will have a higher degree of competitiveness, not only in national but also in international markets.

On the other hand, some theoretical work (Caves, 1982) has argued that firms that produce innovations have incentives to expand into other markets in order to earn higher returns from their investment, since the appropriability regime is improved when widening the market of a product (Teece, 1986). Firms that only operate in domestic markets may find it difficult to recover such investment, either because the market is too small or because it is too costly in terms of time.

In short, the technological capacity of the firm, besides to provide a greater international competitiveness, gives it incentives to enter foreign markets, making it one of the key levers that firms can use to develop their activity successfully abroad. 


\section{DATA AND METHODOLOGY}

\section{Data and sample characteristics}

The data employed in the empirical research come from the Survey of Business Strategies (ESEE, Encuesta sobre Estrategias Empresariales). The ESEE is a statistical investigation that annually (since 1990) surveys a panel of Spanish manufacturing firms on various aspects relating to their strategic behaviour and decisions, and which also includes data from their profit and loss statements and balance sheets. ${ }^{1}$ In the present study we use data from the years 1998 and 1999. We use two years in view of our wish to overcome the problems of causality inherent in crosssectional data referred to in the literature (Salomon \& Shaver, 2000). Thus, the independent variables are taken from the year 1998 and the exports are measured from the year 1999. In addition, it seems logical to think that the effect of the independent variables on export behaviour requires time - i.e., it will not appear immediately, but after a delay. Thus, for the purposes of our research the dynamic perspective is obviously preferable to the static perspective implicit in cross-sectional analysis.

\section{Description of variables}

We now describe the set of variables that we shall use in the econometric analysis that will allow us to test the influence of technological resources on firms' export intensity.

\section{Dependent variables}

We estimated different models to analyse the export intensity of firms. Therefore, the dependent variable will be a percentage variable indicating the proportion of its total sales that are represented by exports (EI).

\section{Independent variables}

Our main independent variable is the firm's level of technological resources. With the aim of obtaining an accurate approximation of these resources we build several variables designed to capture the magnitude of the technological profile of the firm. On the one hand, we build a variable measuring the percentage of the total sales that the firm destines to R\&D investment (R\&D Intensity) - a variable that is widely used in the empirical literature. This variable is complemented by other variables measuring whether the firm undertakes product innovation or not (DP), and the number of product innovations (NP); if the firm undertakes innovations in its productive processes or not (DPROC); and whether it registers patents or not (DPAT), and the number (NPAT). We believe these variables will allow us to obtain a more reliable picture of the technological level of the firm.

\section{Control variables}

We include three control variables: firm size, foreign capital ownership in the firm and a sectorial control variable to take into account other factors that researchers have demonstrated can affect a firm's export behaviour.

Size has been one of the most widely-analyzed variables in the empirical literature on firms' export behaviour (Bonaccorsi, 1992; Calof, 1994), since larger firms are felt to have more resources available to initiate other activities, such as, enter into international markets. The generalised evidence is that larger firms are more likely to export and also - although the consensus is weaker on this point - to export more intensely (Wagner, 2001; Bonaccorsi, 1992). Hence, in the current work we include a variable to control for firm size, defined as the number of total employees in the firm (EMP).

On the other hand, foreign ownership in the capital of the firm may help it to enter in international markets, a result of knowledge about business opportunities in foreign markets or the export experience brought by foreign

\footnotetext{
${ }^{1}$ More information about the ESEE can be found in www.funep.es
} 
alliances (Wignaraja, 2002). We consequently build a dichotomous variable indicating whether the firm has foreign ownership in its capital structure (DFO).

Finally, we include a sectorial control variable. The sectorial context in which a firm operates (the "sector effect") refers to the fact that belonging to a particular industry may condition a firm's strategy and performance in some way. In this regard, numerous empirical studies, above all at the sector level (e.g., Verspagen and Wakelin, 1993; Dosi et al., 1990; Soete, 1987; Hughes, 1986), have shown that sectors intensive in technology export a higher proportion of their output than other sectors. Thus, and in order to control for the "sector effect" on the export behaviour of firms, we build a dichotomous variable indicating whether the sector to which a firm belongs is technology intensive (DTIS). We define technology-intensive sectors as those in which the mean of R\&D expenditure expressed as a proportion of total sales is above the mean expenditure in R\&D for the whole of the sample. According to our data, sectors $3,5,7,8$ and 9 are considered to be technology-intensive sectors (see Appendix). In addition, by isolating the effect of the technology at the sectorial level a much more significant and robust result is obtained vis-àvis the variables measuring firms' technological resources.

\section{Methodology of analysis}

Data analyses are undertaken at two levels. First, descriptive and parametric test statistics are used for comparative analyses. For this, we divide the firms into two groups or categories: on the one hand firms that export and on the other those that do not, and we test if there are technological differences between the two groups. Statistically significant differences will provide us with preliminary evidence on the association between the technological resources of the firm and its export behaviour.

Second, we estimate multiple (nonlinear) regressions models for export intensity. These types of regression models are suitable given the nature of the dependent variable. It is a limited dependent variable whose minimum value is 0 and whose maximum is 1, or $100 \%$ of sales; and in this case the linear regression techniques (OLS) are not appropriate, since the adjusted values of a linear regression are not restricted to lie between 0 and $1^{2}$.

\section{TECHNOLOGYCAL RESOURCES AND EXPORT INTENSITY: EMPIRICAL RESULTS}

\section{Descriptive analysis}

Table 1 reports the comparative statistics of the technology dimension for the two categories of firms: exporting firms and non-exporting firms. As can be seen, there are significant technological differences $(\mathrm{p}<0.01)$ between the two groups of firms. Exporting firms have higher technological capability than non-exporting firms.

\subsection{Econometric analysis}

The econometric analysis of the influence of technological resources on export intensity is carried out with tobit models. We estimate 4 models, which allows us to determine how the technology affects exports more precisely, detecting whether there exists any sensitivity depending on which variables are introduced into the regressions. All the models have a reasonable explanatory power. In the Appendix, we list the technology-intensive sectors and the correlation matrices of the variables.

The results (Table 2) show that all the technological resources variables have a positive and significant effect on export intensity in all the models estimated.

\footnotetext{
${ }^{2}$ More detailed information about these models can be found in Maddala (1983) and Amemiya (1984, 1985).
} 
Table 1. Mean comparison tests

\begin{tabular}{|c|c|c|c|}
\hline & & 1998 & \\
\hline VARIABLES & Exporting firms & Non-exporting firms & Diff \\
\hline R\&D Intensity(\%) & 0.98 & 0.24 & $0.74 * * *$ \\
\hline DP(\%) & 34.46 & 12.2 & $22.26 * * *$ \\
\hline NP & 3.48 & 0.75 & $2.73 * * *$ \\
\hline DPAT(\%) & 9.17 & 1.09 & $8.08 * * *$ \\
\hline NPAT & 0.7 & 0.01 & $0.69 * * *$ \\
\hline DPROC & 49.09 & 23.65 & $25.44 * * *$ \\
\hline $\begin{array}{l}\text { Mean } \\
\text { intensity }(\%)\end{array}$ & 29.59 & 0.00 & $29.59 * * *$ \\
\hline
\end{tabular}

\section{DISCUSSION}

The objective of this work has been to analyse the effect of technological resources on firms' export intensity. In contrast to other works in the literature, the current work has used a very broad measure of firms' technology, since apart from the classic measure of R\&D spending, we have used innovations of products and processes and the patents registered by firms. On the other hand, from the methodological perspective, and in order to avoid problems of causality inherent in the use of cross-sectional data, the independent variables have been measured with a lag of one year, which is also more realistic for the analysis, since a technological variable may take some time to have an effect on firms' export capacity.

From our findings we observe that within the technological component of the firm, R\&D investments, product and processes innovations and the patents registered have a positive and highly significant effect on the export intensity of firms. Indeed, from the perspective of the resource-based theory, technology is one of a firm's main sources of competitive advantage, permitting it to generate competitive advantages based not only on product differentiation but also on cost, which provides the firm with a greater competitive capacity on the international stage and, therefore, contributing to increase its export intensity. In this regard, innovations of products and processes as well as patents are the variables that best reflect these competitive advantages deriving from technology, since in both cases there is a materialisation of the firm's technological capacity. Although it is worth noting that overall, patents have not such a significantly effect on firms'export intensity as product and process innovations have.

These findings are consistent with those of other studies that have analysed the impact of innovation and R\&D investments on the export activity of firms (Özçelik and Taymaz, 2004; Dhanaraj and Beamish; 2003; Roper and Love, 2002; Braunerhjelm, 1996; Kumar and Siddhartan, 1994³; Ito and Pucik, 1993).

As far as the control variables are concerned, both firm size and foreign capital positively and significantly affect the export intensity. With regards the first, this is often considered a stylised fact in the export literature (Wagner, 2001), reflecting the greater availability of resources that larger firms have to venture into international markets. The presence of foreign capital in the ownership structure can provide advantages for exporters - such as a better access to information about foreign markets, logistics and commercial resources, experience - and hence makes it easier for the firm to enter in international markets.

\footnotetext{
${ }^{3}$ In their work, the authors group the firms by sectors and find that spending on $R \& D$ is significant for the industries of medium to low technological level, but not for the high-technology firms.
} 
Table 2. Results of Tobit analysis (dependent variable=EI)a

\begin{tabular}{|c|c|c|c|c|}
\hline Independent Variables & Model 1 & Model 2 & Model 3 & Model 4 \\
\hline C & $\begin{array}{c}-0.034932^{\star *} \\
(-2.278933)\end{array}$ & $\begin{array}{c}-0.022265 \\
(-1.497777)\end{array}$ & $\begin{array}{c}-0.048682^{* * *} \\
(-3.079247)\end{array}$ & $\begin{array}{c}-0.037101^{* * *} \\
(-2.410539)\end{array}$ \\
\hline R\&D Intensity & $\begin{array}{c}1.903671^{\star \star *} \\
(3.864540)\end{array}$ & $\begin{array}{c}2.376909^{\star * \star} \\
(4.996666)\end{array}$ & $\begin{array}{c}1.406430^{\star \star \star} \\
(2.768485)\end{array}$ & $\begin{array}{c}1.841009^{\star \star *} \\
(3.739681)\end{array}$ \\
\hline DP & $\begin{array}{c}0.090880^{\star * *} \\
(3.856943)\end{array}$ & & $\begin{array}{c}0.087715^{* * *} \\
(3.746689)\end{array}$ & \\
\hline NP & & $\begin{array}{l}0.001246^{* *} \\
(1.955041)\end{array}$ & & $\begin{array}{l}0.001199^{\star *} \\
(1.896390)\end{array}$ \\
\hline DPAT & $\begin{array}{c}0.070374^{*} \\
(1.745431)\end{array}$ & & $\begin{array}{c}0.070449^{*} \\
(1.761319)\end{array}$ & \\
\hline NPAT & & $\begin{array}{l}0.008658^{\star *} \\
(2.395289)\end{array}$ & & $\begin{array}{l}0.009085^{\star *} \\
(2.532327)\end{array}$ \\
\hline DPROC & $\begin{array}{c}0.094242^{\star \star *} \\
(4.412644)\end{array}$ & $\begin{array}{c}0.111930^{* * *} \\
(5.393396)\end{array}$ & $\begin{array}{c}0.094138^{* * *} \\
(4.438849)\end{array}$ & $\begin{array}{c}0.111023^{* * *} \\
(5.391080)\end{array}$ \\
\hline EMP & $\begin{array}{c}4.95 \mathrm{E}-05^{* * *} \\
(3.846446)\end{array}$ & $\begin{array}{c}5.27 \mathrm{E}-05^{\star * \star} \\
(4.102160)\end{array}$ & $\begin{array}{c}4.67 \mathrm{E}-05^{* * *} \\
(3.645573)\end{array}$ & $\begin{array}{c}4.96 \mathrm{E}-05^{* * *} \\
(3.881980)\end{array}$ \\
\hline DFO & $\begin{array}{c}0.229687^{* * *} \\
(9.764492)\end{array}$ & $\begin{array}{c}0.232824^{\star \star *} \\
(9.896091)\end{array}$ & $\begin{array}{c}0.209302^{\star \star *} \\
(8.735567)\end{array}$ & $\begin{array}{c}0.211450^{* * *} \\
(8.830212)\end{array}$ \\
\hline DTIS & & & $\begin{array}{c}0.083592^{* * *} \\
(3.614109)\end{array}$ & $\begin{array}{c}0.087574^{* * *} \\
(3.790071)\end{array}$ \\
\hline Indices & & & & \\
\hline R-squared & 0.137811 & 0.141046 & 0.150645 & 0.154877 \\
\hline Adjusted R-squared & 0.132888 & 0.136142 & 0.145099 & 0.149357 \\
\hline Left censored obs & 424 & 424 & 424 & 424 \\
\hline Uncensored obs & 810 & 810 & 810 & 810 \\
\hline Number of firms & 1234 & 1234 & 1234 & 1234 \\
\hline
\end{tabular}

With regards belonging to a technology-intensive sector, the results indicate that the effect is positive and highly significant on export intensity $(\mathrm{p}<0.01)$. This interesting result may indicate that being in a sector that is intensive in technology intensifies the export process as a result of technological spillovers within the industry, externalities and accumulated experience, which allow it to improve its technological capacity at the firm level and hence its competitiveness. This positively affects its export intensity.

\section{CONCLUSIONS}

In this work we have examined how firm's technological resources affect the export intensity of Spanish manufacturing firms. The theoretical framework for analyzing this relationship is based on the resource-based view of the firm and empirically is tested using tobit models.

Our results show that the endowment of firm-technological resources is a key factor in its international competitiveness. R\&D investments, innovations in products and processes as well as patents have a positive and significant effect on firm-export intensity. Moreover, these results hold for all the econometric estimations. 
The practical implications of these results are considerable. First, entrepreneurs and business managers should be aware of the importance of technological resources for the international competitiveness of their firms, and hence of the need to improve the firm-technological profile. This will guarantee the firm success in international markets and its capacity to expand abroad. Second, the Public Administration should provide help in this track by implementing policies that promote and stimulate $R \& D$ investments and innovations inside the firm. This will contribute to create a more competitive industry.

As for future lines of research in this area, there are many questions to consider. First, we can extend this analysis to the export propensity, i.e. the likelihood of being an exporter, in order to know if the results for export intensity hold for the export/no export decision. Second, another interesting question is to analyze if a higher degree of export intensity translate into superior financial performance, or if there are fundamental financial/structural differences among exporters and domestic units.

\section{REFERENCES}

1. Alonso, J.A. and Donoso, V. (1998) Competir en el exterior. La empresa española y los mercados internacionales. ICEX, Madrid.

2. $\quad$ Amemiya, T. (1984). Tobit models: A survey. Journal of Econometrics, 24, 3-61.

3. Amemiya, T. (1985). Advance Econometrics, Harvard University Press.

4. Amit, R. and Schoemaker, P. (1993). Strategic assets and organizational rent. Strategic Management Journal, $14,33-46$.

5. Barney, J.B. (1991). Firm resources and sustained competitive advantage. Journal of Management, 17, 99120.

6. Basile, R. (2001). Export Behaviour of Italian manufacturing firms over the nineties: The role of innovation. Research Policy, 30, 1185-1201.

7. Bonaccorsi, A. (1992). On the relationship between firm size and export intensity. Journal of International Business Studies, 23, 605-635.

8. Burton, F. N. and Schlegelmilch, B. B. (1987). Profile analysis of non-exporters versus exporters grouped by export involvement. Management International Review, 27, 38-49.

9. Braunerhjelm, P. (1996). The relation between firm-specific intangibles and export. Economic Letters, 53, 213-219.

10. Calof, J.L. (1994). The relationship between firm size and export behaviour revisited. Journal of International Business Studies, Second term, 367-387.

11. Caves, R.E. (1982). Multinational enterprise and economic analysis. Cambridge: Cambridge University Press.

12. Cavusgil, S.T. and S. Zou. (1994). Marketing strategy-performance relationship: An investigation of the empirical link in export market ventures. Journal of Marketing, 58, 1-21.

13. Cavusgil, S.T., Zou. S., and Naidu, G.M. (1993). Product and promotion adaptation in export ventures: An empirical investigation. Journal of International Business Studies, 24, 479-506.

14. Dhanaraj, C. and Beamish, P. (2003). A resource-based approach to the study of export performance. Journal of Small Business Management, 41, 242-261.

15. Dosi, G., Pavitt, K. and Soete, L. (1990). The Economic of technical change and international trade. Harvester, NY.

16. Hughes, K. (1986). Exports and technology. Cambridge: Cambridge University Press

17. Grant, R.M. (1991). "The resource-based theory of competitive advantage: Implications from strategy formulation". California Management Review, 33, pp. 114-135.

18. Gourlay, A. and Seaton, J. (2003). Export intensity in UK firms. Applied Economics Letters, 10, 471-477.

19. Itami, H. (1987). Mobilizing invisible assets. Harvard University Press. Cambridge. Massachussets.

20. Ito, K. and Pucik, V. (1993). R\&D spending, domestic competition, and export performance of Japanese manufacturing firms. Strategic Management Journal, 14, 61-75.

21. Kogut, B. and Zander, U. (1993). Knowledge of the firm and the evolutionary theory of the multinational corporation. Journal of International Business Studies, 24, 625-645. 
22. Kirpalani, V.H. and Macintosh, N.B. (1980). Internal marketing effectiveness of technology-oriented small firms. Journal of International Business Studies, 11, 81-90.

23. Kumar, N. and Siddharthan, N.S. (1994). Technology, firm size and export behaviour in developing countries: The case of Indian enterprise. Journal of Development Studies, 32, 288-309.

24. Lefebvre, E.,Lefebvre, L.A. and Bourgault, M. (1998). R\&D-related capabilities as determinants of export performance. Small Business Economics, 10, 365-377.

25. Maddala, G. S. (1983). Limited Dependent and Quantitative Variables in Econometrics, Cambridge University Press.

26. Madsen, T.K. (1989). Successfull export marketing management: Some empirical evidence. International Marketing Review, 6, 41-57.

27. Mcguinness, N.W. and Little, B. (1981). The influence of product characteristics on the export performance of new industrial products. Journal of Marketing, 110-122.

28. Nassimbeni, G. (2001). Technology, innovation capacity, and the export attitude of small manufacturing firms: A logit/tobit model. Research Policy, 30, 245-262.

29. Özçelik, E. and Taymaz, E. (2004). Does innovativeness matter for international competitiveness in developing countries? The case of Turkish manufacturing industries. Research Policy, vol. 33, 409-425.

30. Penrose, E. T. (1959). The theory of the growth of the firm. Ed. Oxford:Blackwell.

31. Roper, S. and Love, J. (2002). Innovation and export performance: Evidence from the UK and German manufacturing plants. Research Policy, 31, 1087-1102.

32. Salomon, R and Shaver, J.M. (2000) Firm and exchange rate determinants of export and domestic sales, Academy of international Annual Meetings, Phoenix, November.

33. Smith, V., Strojer, E. and Dilling-Hansen, M. (2002). Export performance and Investment in R\&D. WP 2002/4, The Danish Institute for Studies in Research and Research Policy.

34. Soete, L. (1987). The impact of technological innovation on international trade patterns: The evidence reconsidered. Research Policy, 16, 101-130.

35. Starlacchini, A. (1999). The determinants of export performance: a firm-level study of Italian manufacturing. Weltwirtschatliches Archiv, 137, 450-472.

36. Styles, C. and Ambler, T. (1994). Successful export practice: the UK experience. International Marketing Review, 11, 23-47.

37. Teece, D.J. (1986). Profiting from technological innovation. Research Policy, 15, 285-306.

38. Verspagen, B. and Wakelin, K. (1993). International competitiveness and its determinants, Maastricht: MERIT, mimeo. 93-008.

39. Wagner, J. (1996). Export performance, human capital and product innovation in German: A micro view. $J b . f$. Wirtschaftswissenschaften, 47, 40-45.

40. Wagner, J. (2001). A note on the firm size-export relationship. Small Business Economics, 17, 229-237.

41. Wakelin, K. (1998). Innovation and export behaviour at the firm level. Research Policy, 26, 829-841.

42. Wernerfelt, B. (1984). A resource-based view of the firm. Strategic Management Journal, 16, 171-180.

43. Wignaraja, G. (2002). Firm size, technological capabilities and market-orientated policies in Mauritius. Oxford Developmente Studies, 30, 87-105.

44. Willmore, L. (1992). Transnationals and foreign trade: Evidence from Brazil. Journal of Development Studies, 28, 314-335. 


\section{Appendix 1: Technology Intensive Sectors}

\section{SECTOR}

1. Ferrous and non-ferrous metals

2. Non-metalic mineral products

3. Chemicals

4. Metal products

5. Industrial machinery

6. Computing

7. Electrical machinery

8. Vehicles

9. Other transport industry

10. Meat and preserved food

11. Food and tobacco

12. Beverages

13. Textiles

14. Leather and footwear

15. Wood and furniture

16. Paper and printing

17. Rubber and plastics

18. Other manufacturing
R\&D/Sales (\%)

0.34

0.4

$2.08^{*}$

0.35

1.01 *

0.69

$1.85^{*}$

$1.08^{*}$

$3.18^{\star}$

0.12

0.16

0.1

0.42

0.31

0.14

0.31

0.38

0.52

Mean R\&D total sectors

0.71

* Sectors intensive in R\&D

Appendix 2. Correlation matrix and descriptive statistics

\begin{tabular}{lcccccccccccc}
\hline \multicolumn{1}{c}{} & Mean & Estandar D. & 1 & 2 & 3 & 4 & 5 & 6 & 7 & 8 & 9 \\
\hline 1. R\&D Intensity & 0.007 & 0.020 & 1 & & & & & & & & \\
2. DP & 0.278 & 0.448 & 0.280 & 1 & & & & & & & \\
3. NP & 2.743 & 14.383 & 0.073 & 0.306 & 1 & & & & & & \\
4. DPAT & 0.066 & 0.066 & 0.230 & 0.185 & 0.015 & 1 & & & & & \\
5. NPAT & 0.066 & 2.563 & 0.101 & 0.110 & 0.060 & 0.384 & 1 & & & & \\
6. DPROC & 0.391 & 0.488 & 0.170 & 0.303 & 0.099 & 0.133 & 0.076 & 1 & & & \\
7. EMP & 288.464 & 803.583 & 0.195 & 0.162 & 0.039 & 0.062 & 0.064 & 0.150 & 1 & & \\
8. DFO & 0.241 & 0.428 & 0.065 & 0.116 & 0.036 & 0.029 & 0.006 & 0.151 & 0.279 & 1 & \\
9. DTIS & 0.154 & 0.361 & 0.297 & 0.135 & 0.039 & 0.080 & 0.006 & 0.071 & 0.163 & 0.247 & 1 \\
\hline
\end{tabular}




\section{NOTES}

